\title{
STABILITY STUDIES OF CEFTIOFUR SODIUM IN AQUEOUS SOLUTIONS AND IN THE SOLID PHASE
}

\author{
AGNIESZKA DOŁHAŃ, AGNIESZKA SOBCZAK, IZABELA MUSZALSKA*, \\ BEATA MEDENECKA, PIOTR GARBACKI, SZYMON TOMCZAK and ANNA JELIŃSKA
}

Department of Pharmaceutical Chemistry, Faculty of Pharmacy, Poznan University of Medical Sciences, Poznań, Poland

\begin{abstract}
Ceftiofur sodium (CFT), a third-generation cephalosporin for parenteral use, is commonly used in veterinary medicine against aerobic Gram-positive and Gram-negative bacteria as well as certain anaerobes. Its broad spectrum of activity and resistance to beta-lactamases result from the presence of methoxyimino and aminothiazole moieties at C-7 in the cephalosporin structure. The aim of this study was a comprehensive evaluation of the stability of CFT in the solid phase and in aqueous solutions. A fast and sensitive HPLC isocratic method was used for the determination of CFT degradation in the solid phase and in aqueous solutions. CFT degradation occurred according to a first-order reaction depending on the substrate concentration. The kinetic and thermodynamic parameters of CFT degradation in the solid phase were calculated. General acid-base hydrolysis of CFT was not observed in the solutions of hydrochloric acid, sodium hydroxide, phosphate $(\mathrm{pH}$ $5.84-7.25)$, acetate ( $\mathrm{pH} 3.65-5.48)$ and borate ( $\mathrm{pH} 7.49-10.07)$ buffers. CFT was the most stable in the $\mathrm{pH}$ range $2-6$. The susceptibility of CFT to degradation under the influence of stress factors $(\mathrm{pH}$, temperature, buffer components concentration, relative air humidity) should be considered in terms of storage conditions and the preparation of the product for administration.
\end{abstract}

Keywords: solid phase, stability, kinetic parameters, thermodynamic parameters

Stability evaluation is an integral part of quality studies of substances for pharmaceutical use and it is conducted to establish whether the therapeutic effectiveness and safety of a given drug can be guaranteed over the entire period of its shelf life.

Diseases of bacterial etiology pose a challenge in the treatment of people and animals. A significant therapeutic limitation involved in the use of antibacterial drugs in veterinary medicine results from the need to ensure that a particular drug is safe not only for animals but also for their handlers and consumers of animal food products (1-10).

The treatment of infectious animal diseases is based mainly on beta-lactam antibiotics, where the beta-lactam bond determines their antibacterial activity. This bond irreversibly acetylates the $-\mathrm{CH}_{2} \mathrm{OH}$ group of biocatalysts (transpeptidase, carboxypeptidase, and endopeptidase), which inhibits the biosynthesis of the bacterial cell wall (11).

Several factors affect the stability and effectiveness of beta-lactam antibiotics. The hydrolysis or degradation of the beta-lactam bond due to an increased temperature or relative air humidity may result in the loss of antibiotic activity. It has also been observed that the susceptibility of beta-lactam antibiotics to the action of bacterial enzymes leads to the development of bacterial resistance.

Ceftiofur sodium (CFT, $(6 R-(6 \alpha, 7 \beta(Z)))-7$ (((2-amino-4-thiazolyl)(methoxyimino)-acetyl)amino)-3-(((2-(furanylcarbonyl)thio)methyl))-8oxo-5-thia-1-azabicyclo[4.2.0]oct-2-ene-2-carboxylic acid sodium salt (Fig. 1)) is a third-generation cephalosporin that is commonly used in veterinary medicine (12).

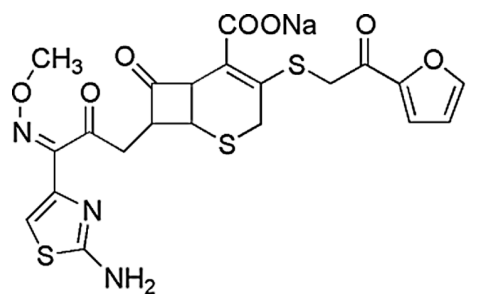

Figure 1. Chemical structure of ceftiofur sodium

\footnotetext{
* Corresponding author: e-mail: imuszals@ump.edu.pl
} 
Ceftiofur sodium is potent against aerobic Gram-positive and Gram-negative bacteria as well as certain anaerobes (Actinobacillus pleuropneumoniae, Escherichia coli, Haemophilus parasuis, Haemophilus somnus, Pasteurella hemolitica, Pasteurella multocida and Streptococcus suis (13-20). The broad activity spectrum and the resistance of ceftiofur sodium to beta-lactamases result from the presence of methoxyimino and aminothiazole moieties at C-7 in the cephalosporin structure.

CFT has been approved for the treatment of respiratory diseases in swine, cattle, sheep, goats, and horses, and for the management of foot rot and metritis infections in cattle as well as for the prevention of early mortality infections in day-old chicks (21-26). It is administered subcutaneously into inedible animal tissues. The drug withdrawal time for edible tissues is 9 days. The maximum residues limit (MRL), which is the sum of all residues containing the beta-lactam bond, depends on the target tissue.

It is poorly absorbed upon oral administration but its absorption improves when administered subcutaneously or intramuscularly. The drug forms a strong bond with serum proteins (ca. 70-90\%) (27). Ceftiofur is vulnerable to degradation under various conditions such as acid, alkaline, and enzyme-catalyzed hydrolysis, producing a number of unstable degradation products (28-33).

Under controlled alkaline conditions, the primary hydrolysis product is desfuroylceftiofur, which is the most abundant metabolite in bovine blood. Its activity against pathogens is similar to that of ceftiofur. Desfuroylceftiofur is readily hydrolyzed or oxidized to more complex products, for example, a disulfide dimer (urinary metabolite of ceftiofur sodium in rats and cattle). Under acidic conditions, desfuroylceftiofur is converted to the corresponding thiolactone. Thiofuroic acid is formed by a cleavage on the alkyl side of the thioester bond (34-36).

In aqueous solutions, the rate of CFT degradation at $60^{\circ} \mathrm{C}$ has been found to be significantly higher at $\mathrm{pH} 7.4$ than at $\mathrm{pH} 1,3$ or 5 and when compared to the degradation rate in distilled water. Degradation in buffer at $\mathrm{pH} 10$ was rapid, with no detectable ceftiofur levels present at the end of 10 min incubation, both at $60^{\circ} \mathrm{C}$ and $25^{\circ} \mathrm{C}$. The rate of degradation increased in all aqueous solutions as the incubation temperature rose (28-30). Photostability tests of ceftiofur have also been carried out. They demonstrated that since ceftiofur was susceptible to photodegradation, it should be protected from light during preparation (31). The oxidation products of cef- tiofur formed in hydrogen peroxide solution have been identified with the use of HPLC/Electrospray Ionization/Tandem Mass Spectrometry. They were identified as compounds oxidized at the sulfur of the cephem ring (32). The stability of ceftiofur sodium has also been studied in intravenous solutions (33), using mainly HPLC methods (28-33).

To the best of our knowledge, the kinetic and thermodynamic parameters of ceftiofur sodium degradation in the solid phase have not been reported. Studies of CFT stability in aqueous solutions have not examined general acid-base catalysis (buffer type and concentration) or specific catalysis in a broad $\mathrm{pH}$ range. Hence, the $\mathrm{k}_{\mathrm{pH}}$ profile as a function of $\mathrm{pH}$ has not been determined.

The aim of this study was a comprehensive evaluation of the stability of CFT in the solid phase and in aqueous solutions. In the solid phase, the effect of temperature on ceftiofur sodium stability at a relative air humidity of approx. $76 \%$ and $0 \%$, and the influence of relative air humidity $(\mathrm{RH}=66.5 \%-$ $90.0 \%$ ) at $363 \mathrm{~K}$ were investigated. In aqueous solutions ( $\mathrm{pH} 0.44-12.43$ ), the influence of hydrogen ion concentrations and the type and concentrations of buffer components at $323 \mathrm{~K}$ were examined. To determine the observed rate constants, an isocratic HPLC-UV method was used.

\section{EXPERIMENTAL}

\section{Samples preparation}

Ceftiofur sodium (CFT) (MOLECULA, Shaftesbury, United Kingdom) (Fig. 1) is a white, crystalline powder, soluble in water, slightly soluble in 1,3-propanediol and sparingly soluble in 1,2propanediol. All other chemicals and solvents were obtained from Merck KGaA, Germany, and were of analytical or high-performance liquid chromatographic grade. High-quality pure water was prepared by using a Millipore purification system (Millipore Exil SA 67120, Milsheim, France).

\section{Chromatographic conditions}

Chromatographic separation and quantitative analysis were performed by using an HPLC method developed by Souza et al. (28) and modified and validated in the Department of Pharmaceutical Chemistry, Poznan University of Medical Sciences (33). The analytical system consisted of a Shimadzu SPD20A Prominence UV/VIS detector, a Rheodyne with a $50 \mu \mathrm{L}$ loop. A LiChrospher RP-18 column (250 $\mathrm{mm} \times 4.6 \mathrm{~mm}, 5 \mu \mathrm{m}$ particle size, Merck, Germany) was used as the stationary phase. The mobile phase consisted of a mixture of 22 volumes of acetonitrile 
and 78 volumes of phosphate buffer (0.02 M: 0.017 $\mathrm{M} \mathrm{KH}_{2} \mathrm{PO}_{4}, 0.003 \mathrm{M} \mathrm{Na}_{2} \mathrm{HPO}_{4} ; \mathrm{pH}=6.0$ ). The flow rate was $1.2 \mathrm{~mL} / \mathrm{min}$ and $\mathrm{UV}$ detection was performed at $292 \mathrm{~nm}$. Although the method was evaluated and validated for the stress degradation study, the selectivity was examined during the stability study of CFT.

\section{Kinetic procedures}

For the forced aging test in the solid phase, 5.0 mg samples of ceftiofur sodium were weighed into $5 \mathrm{~mL}$ open vials and the influence of temperature and relative air humidity was studied. The impact of temperature was examined at approx. $\mathrm{RH} 76.4 \%$ and $0 \%$. To evaluate stability at increased air humidity $(\sim 76.4 \%)$, the samples in desiccators with a saturated solution of $\mathrm{NaCl}$ were placed in the heat chambers at $333,343,353$ and $363 \mathrm{~K}$ whereas in dry air, the vials were immersed in a sand bath placed in the heat chambers at $353,363,373$ and $383 \mathrm{~K}$. The temperature control accuracy of the heat chambers was $\pm 1.0 \mathrm{~K}$.

The influence of relative air humidity was investigated under isothermal conditions at $\mathrm{RH}$ $66.5 \%-90.0 \%$, at $363 \mathrm{~K}$. To obtain the desired RH value the following saturated salt baths were used: sodium nitrate (RH 66.5\%), sodium chloride (RH 76.4\%) and zinc sulfate (RH 90.0\%). To equilibrate the test conditions, the so-obtained salt baths were incubated at the desired temperature for $24 \mathrm{~h}$ before insertion of the ceftiofur samples.

At specified time intervals, determined by the rate of degradation, the vials were removed, cooled to room temperature, and their contents were dissolved in distilled water. The so-obtained solutions were quantitatively transferred into measuring flasks and diluted with water to $25.0 \mathrm{~mL}$.

The degradation of CFT in aqueous solutions was studied at $323 \mathrm{~K}$, in the $\mathrm{pH}$ range $0.44-12.43$. The $\mathrm{pH}$ values of the reaction solutions and those of the buffer standards were measured at the reaction temperature. The $\mathrm{pH}$ values of the reaction solutions in $\mathrm{HCl}$ and $\mathrm{NaOH}$ were calculated from the equations:

$$
\begin{gathered}
\mathrm{pH}=-\operatorname{logf}_{\mathrm{HCl}} \cdot[\mathrm{HCl}] \text { or } \\
\mathrm{pH}=\mathrm{pKW}+\log _{\mathrm{NaOH}} \cdot[\mathrm{NaOH}]
\end{gathered}
$$

The activity coefficients $\mathrm{f}_{\mathrm{HCl}}$ and $\mathrm{f}_{\mathrm{NaOH}}$ were obtained or calculated from the literature data (37). The ionic strength of all the solutions was adjusted to $0.50 \mathrm{M}$ with a solution of sodium chloride (4 M). Solutions of the desired $\mathrm{pH}$ and ionic strength of $0.50 \mathrm{M}$ were heated to $323 \mathrm{~K}$ and then a sample of CFT was added. The initial concentration of CFT was $0.2 \mathrm{mg} / \mathrm{mL}$. At selected times, determined by the rate of degradation, samples of the solutions (1.0 $\mathrm{mL}$ ) were collected and instantly cooled with a mixture of ice and water. Samples with $\mathrm{pH}$ above 7.5 were neutralized by using $\mathrm{HCl}$ solutions at appropriate concentrations. $50 \mu \mathrm{L}$ of samples of the solutions were injected onto the column.

\section{RESULTS AND DISCUSSION}

The HPLC method with UV detection developed for the determination of ceftiofur sodium under the stress conditions of hydrolysis, oxidation, photolysis and thermal degradation was found suitable for a degradation study in the solid phase and in aqueous solutions (28). In the present study, the selectivity of the HPLC method in the presence of CFT degradation products was confirmed, since in the chromatograms the symmetrical peak of analyzed substance $\left(t_{R}=6.75\right.$ $\mathrm{min}$ ) was well separated from the peak of the degradation product ( $t_{\mathrm{R}}=2.82 \mathrm{~min}$ ) (Fig. 2).

\section{Stability of ceftiofur sodium in the solid phase}

The study of CFT degradation in the solid phase was conducted under conditions of increased

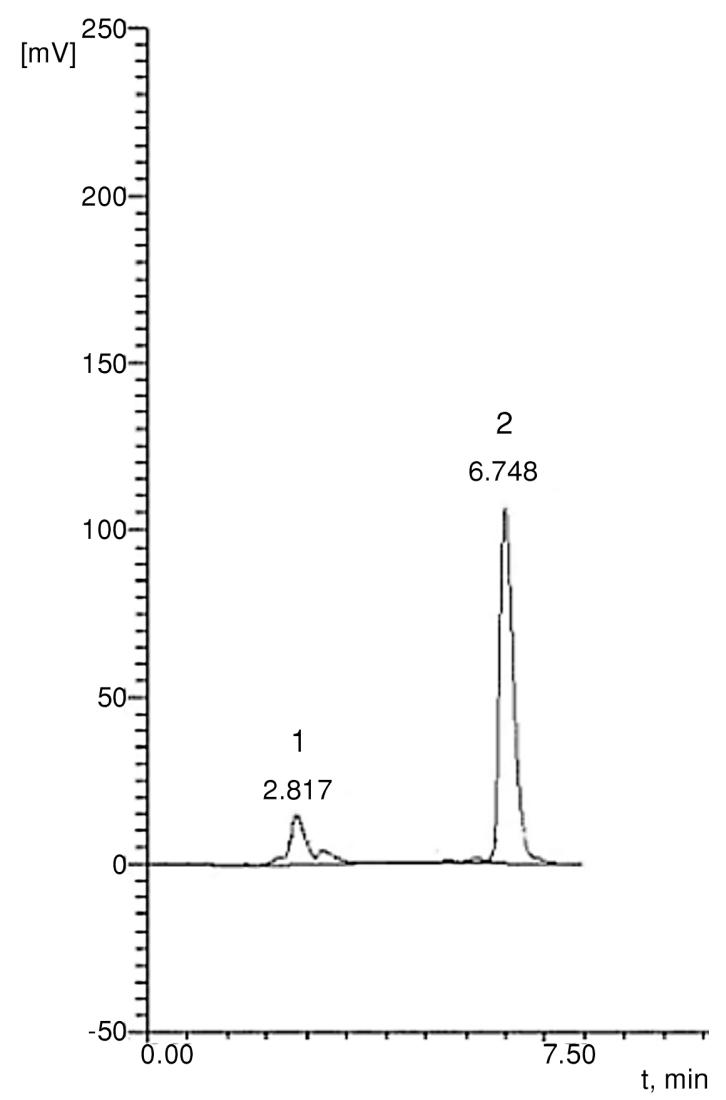

Figure 2. HPLC chromatogram of ceftiofur sodium under the degradation factors $(1$ - degradation products, 2 - ceftiofur sodium) 
temperature and varying relative air humidity to simulate degradation in commercial packaging.

During the degradation of ceftiofur sodium in the solid phase, its concentration decreased in the time interval $t_{0} \rightarrow t_{\infty}$ from $\left(c_{t}\right)_{\max }$ to $c_{0}$. The degradation of ceftiofur sodium under the influence of temperature in dry air and at increased relative air humidity was a first-order reaction depending on the substrate concentration and is described by equation 2 :

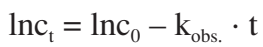

where: $c_{t}$ and $c_{0}-$ the time-dependent concentration and the initial concentration of CFT at time $\mathrm{t}>0$ and

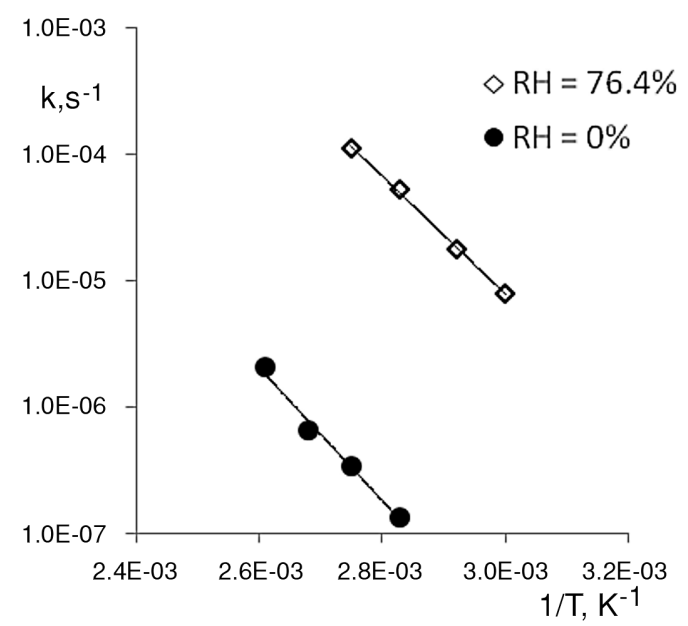

Figure 3. Arrhenius relationships for the degradation of ceftiofur sodium at $\mathrm{RH} 76.4 \%$ and $0 \%$ $\mathrm{t}=0$, respectively, $\mathrm{k}_{\mathrm{obs}}$ - the observed rate constant. The number of measurements of $c_{t}$ for each series ranged from 8 to 12 . The semilogarithmic plots $\ln \mathrm{c}_{\mathrm{t}}=f(\mathrm{t})$ were linear and their slopes were equal to the rate constants of the reaction with the negative sign $\left(-\mathrm{k}_{\mathrm{obs}}\right)$ (Table 1$)$. The least squares method was used to calculate the regression parameters $y=a x+$ $b, a \pm \mathrm{D} a$, and $b \pm \mathrm{D} b$, standard errors $S_{a}, S_{b}$ and $S_{y}$, and the correlation coefficient $r$. The $\pm \mathrm{D} a$ and $\pm \mathrm{D} b$ were estimated for $f=n-2$ degrees of freedom and $\mathrm{a}=0.05$.

\section{Thermodynamic parameters of CTF degradation in the solid phase}

The effect of temperature on the degradation of ceftiofur sodium was studied by conducting the degradation at four different temperatures, at $\mathrm{RH}=$ $0 \%$ and $\mathrm{RH}=\sim 76.4 \%$. The relationship between the observed rate constants and temperature is described by the Arrhenius equation:

$$
\mathrm{n}_{\mathrm{k}_{\mathrm{i}}}=\ln \mathrm{A} \mathrm{A}-\frac{\mathrm{E}_{a}}{\mathrm{R} \cdot \mathrm{T}}
$$

where: $k_{i}-$ the observed rate constant of ceftiofur sodium $\left[\mathrm{s}^{-1}\right], \mathrm{A}$ - frequency coefficient, $\mathrm{E}_{a}-$ activation energy $\left[\mathrm{J} \mathrm{mol}^{-1}\right], \mathrm{R}-$ the universal gas constant [8.3144 $\left.\mathrm{J} \mathrm{K}^{-1} \mathrm{~mol}^{-1}\right]$, and $\mathrm{T}$ - temperature $[\mathrm{K}]$.

The straight-line relationships $\ln \mathrm{k}_{\mathrm{i}}=\mathrm{f}(1 / \mathrm{T})$ were obtained for ceftiofur sodium in the temperature range $333-363 \mathrm{~K}$, at increased relative air humidity $(76.4 \%)$, and in dry air in the range $353-$ 383 K (Fig. 3). The least squares method was used to calculate the slopes (a) and the frequency coeffi-

\begin{tabular}{|c|c|c|c|}
\hline Temperature $[\mathrm{K}]$ & $(\mathrm{k} \pm \Delta \mathrm{k})\left[\mathrm{s}^{-1}\right]$ & $\begin{array}{l}\text { Statistical evaluation of } \\
\qquad \ln \mathrm{k}_{\mathrm{i}}=\mathrm{f}(1 / \mathrm{T})\end{array}$ & Thermodynamic parameters \\
\hline & & $\mathrm{RH}=76.4 \%$ & \\
\hline \multirow[t]{2}{*}{$\begin{array}{l}333 \\
343 \\
353 \\
363\end{array}$} & $\begin{array}{l}(7.95 \pm 0.32) \times 10^{-6} \\
(1.76 \pm 0.36) \times 10^{-5} \\
(5.26 \pm 0.30) \times 10^{-5} \\
(1.12 \pm 0.22) \times 10^{-4}\end{array}$ & $\begin{array}{c}a \pm \Delta \mathrm{a}=(-10.9 \pm 0.2) 10^{3} \\
\mathrm{~S}_{a}=563.2 \\
b \pm \Delta b=21.0 \pm 7.0 \\
\mathrm{~S}_{b}=1.6 \\
\mathrm{r}=-0.9973 \\
\mathrm{~S}_{\mathrm{y}}=0.1 \\
\mathrm{n}=4\end{array}$ & $\begin{array}{c}E_{a}=90.7 \pm 20.1\left(\mathrm{~kJ} \mathrm{~mol}^{-1}\right) \\
\Delta H^{\neq \mathrm{a}}=88.3 \pm 20.1\left(\mathrm{~kJ} \mathrm{~mol}^{-1}\right) \\
\Delta S^{\neq \mathrm{a}}=-70.3 \pm 57.9\left(\mathrm{JK}^{-1} \mathrm{~mol}^{-1}\right)\end{array}$ \\
\hline & & $\mathrm{RH}=0 \% 353$ & \\
\hline $\begin{array}{l}353 \\
363 \\
373 \\
383\end{array}$ & $\begin{array}{l}(1.33 \pm 0.37) \times 10^{-7} \\
(3.34 \pm 0.77) \times 10^{-7} \\
(6.43 \pm 0.96) \times 10^{-7} \\
(2.05 \pm 0.28) \times 10^{-6}\end{array}$ & $\begin{array}{c}a \pm \Delta a=(-12.0 \pm 0.4) 10^{3} \\
\mathrm{~S}_{a}=1023.9 \\
b \pm \Delta b=18.0 \pm 12.0 \\
\mathrm{~S}_{b}=2.8 \\
\mathrm{r}=-0.9927 \\
\mathrm{~S}_{\mathrm{y}}=0,2 \\
\mathrm{n}=4\end{array}$ & $\begin{array}{c}E_{a}=99.4 \pm 36.6\left(\mathrm{~kJ} \mathrm{~mol}^{-1}\right) \\
\Delta H^{\neq \mathrm{a}}=97.0 \pm 36.7\left(\mathrm{~kJ} \mathrm{~mol}^{-1}\right) \\
\Delta S^{\neq \mathrm{a}}=-95.1 \pm 99.7\left(\mathrm{JK}^{-1} \mathrm{~mol}^{-1}\right)\end{array}$ \\
\hline
\end{tabular}

Table 1. Kinetic and thermodynamic parameters of the degradation of ceftiofur sodium in the solid phase at RH $0 \%$ and $76.4 \%$

$\Delta k=S_{a} \cdot t_{0.05}(n-2) ; E_{a}$, activation energy; $\Delta H^{\ddagger}$, enthalpy; $\Delta S^{\ddagger}$, entropy; $E_{a}=-a R ; \Delta H^{\ddagger}=E_{a}-T R ; \Delta S^{\neq}=R\left(\ln A \ln \left(k_{b} T\right) / h\right)$ where: $\mathrm{k}_{\mathrm{B}}$, Boltzmann's constant $\left(1.380710^{-23} \mathrm{JK}^{-1}\right) ; h$, Planck's constant $\left(6.62610^{-34} \mathrm{Js}\right) ; R$, universal gas constant $\left(8.314 \mathrm{~J} \mathrm{~K}^{-1} \mathrm{~mol}^{-1}\right), T$, temperature in $\mathrm{K}(\mathrm{t}+273 \mathrm{~K})$; $a$, vectorial coefficient of the Arrhenius; $A$, frequency coefficient $a$ calculated for $298 \mathrm{~K}$ 
cient $(\ln \mathrm{A})$, which allowed calculation of activation energy $\left(\mathrm{E}_{a}=-\mathrm{a} \times \mathrm{R}\right)$, enthalpy $\left(\Delta \mathrm{H}^{\mp}\right)$ and entropy $\left(\Delta \mathrm{S}^{\ddagger}\right)$ at $298 \mathrm{~K}$ (Table 1$)$.

The activation energy of the degradation of ceftiofur sodium at $\mathrm{RH}=0 \%$ and $\mathrm{RH}=76.4 \%$ was not significantly different $\left(\mathrm{E}_{a}\right.$ at $\mathrm{RH}=0 \%=99.4$ $\left[\mathrm{kJ} \cdot \mathrm{mol}^{-1}\right], \mathrm{E}_{a}$ at $\left.\mathrm{RH}=76.4 \%=90.7\left[\mathrm{~kJ} \cdot \mathrm{mol}^{-1}\right]\right)$, which was confirmed by the parallelism test: $\mathrm{t}_{\text {cal }}=$ $1.33=2.78<\mathrm{t}_{0.05}$. Thus, the storage conditions did not affect CFT stability.

At elevated relative air humidity, the rate of CFT degradation increased, as proved by lower $\mathrm{E}_{\mathrm{a}}$ and $\Delta \mathrm{H}^{?}$ values compared to those obtained at $\mathrm{RH}=$ $0 \%$. The positive values of $\Delta \mathrm{H}^{\neq}$confirmed the endothermal character of the reaction. The negative values of $\Delta \mathrm{S}^{\ddagger}$ probably indicated the bimolecular character of degradation. The value $\mathrm{k}_{0}=2.45 \cdot 10^{-5} \mathrm{~s}^{-1}$ at $363 \mathrm{~K}$, determined from the dependence $\ln \mathrm{k}_{\mathrm{i}}=$ $\mathrm{f}(\mathrm{RH} \%)$, and the value $\mathrm{k}_{363 \mathrm{~K}, 0 \% \mathrm{RH}}=3.34 \cdot 10^{-7} \mathrm{~s}^{-1}$, determined from the dependence $\ln k_{i}=f(1 / T)$, varied significantly, which demonstrated different mechanisms of ceftiofur sodium degradation at $\mathrm{RH}=$ $0 \%$ and at increased relative air humidity, despite the same kinetic mechanisms of the reaction (Fig. 4).

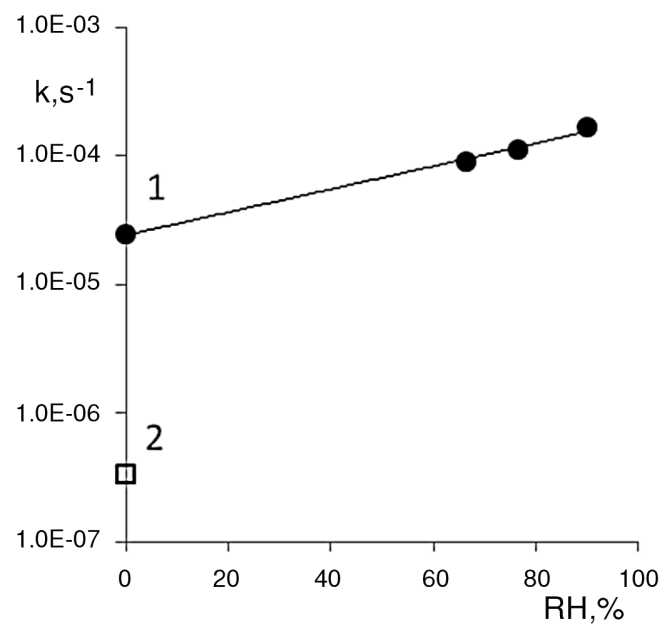

Figure 4. Semilogarythmic relationship $\mathrm{k}_{\mathrm{i}}=\mathrm{f}(\mathrm{RH} \%)$ for the degradation reaction of ceftiofur sodium in the solid phase. $1-\mathrm{k}_{0}$ for $\mathrm{RH}=0 \%$ at $363 \mathrm{~K}, 2-\mathrm{k}_{363}$ for $\mathrm{RH}=0 \%$ calculated from the dependence $\ln \mathrm{k}_{\mathrm{i}}=\mathrm{f}(1 / \mathrm{T})(\mathrm{Eq}, 3)$
Stability of ceftiofur sodium in aqueous solutions

The degradation of ceftiofur sodium in aqueous solutions was a pseudo-first-order reaction described by equation 2 .

Buffer catalysis. At a constant $\mathrm{pH}$, ionic strength and temperature, the rate constants $\left(\mathrm{k}_{\mathrm{obs}}\right)$ for the degradation of CFT increased linearly as the total concentrations of the phosphate buffer $(\mathrm{pH}$ $1.54-2.95, \mathrm{H}_{3} \mathrm{PO}_{4}$ and $\mathrm{H}_{2}$ Pincreased. Since the observed rate constant is a sum of catalytic rate constants catalyzed by the buffer components $\left(\mathrm{k}_{\mathrm{B}}\right)$ and the rate constants at zero buffer concentration $\left(\mathrm{k}_{\mathrm{pH}}\right)$, under the conditions of general acid-base catalysis the $\mathrm{k}_{\mathrm{obs}}$ were calculated from the following equation:

$$
\mathrm{k}_{\text {obs. }}=\mathrm{k}_{\mathrm{pH}}+\mathrm{k}_{\mathrm{B}} \cdot[\mathrm{B}]_{\mathrm{T}}
$$

where: $[\mathrm{B}]_{\mathrm{T}}-$ the total buffer concentration, $\mathrm{k}_{\mathrm{pH}}-$ the rate constant at zero buffer concentration, $\mathrm{k}_{\mathrm{B}}-\mathrm{a}$ composite rate constant including the catalytic effects of the phosphate buffer $\left(\mathrm{pK}_{\mathrm{a}}=2.10\right)$. The plots $\mathrm{k}_{\mathrm{obs}}=\mathrm{f}\left([\mathrm{B}]_{\mathrm{T}}\right)$ obtained for phosphate buffer were linear and their slopes equaled $\mathrm{k}_{\mathrm{B}}$ whereas the values of $\mathrm{k}_{\mathrm{obs}}$ for $[\mathrm{B}]_{\mathrm{T}}=0$ equaled $\mathrm{k}_{\mathrm{pH}}$. In the case of this buffer

$$
\begin{gathered}
\mathrm{k}_{\mathrm{B}}=\mathrm{k}_{\mathrm{H}_{3} \mathrm{PO}_{4}} \cdot\left[\mathrm{H}_{3} \mathrm{PO}_{4}\right]+\mathrm{k}_{\mathrm{H}_{3} \mathrm{PO}_{4}^{-}} \cdot\left[\mathrm{H}_{2} \mathrm{PO}_{4}^{-}\right] \\
\mathrm{k}_{\text {obs. }}=\mathrm{k}_{\mathrm{pH}}+[\mathrm{B}]_{\mathrm{T}} \frac{\mathrm{k}_{\mathrm{H}_{3} \mathrm{PO}_{4}} \cdot\left[\mathrm{H}^{+}\right]+\mathrm{k}_{\mathrm{H}_{3} \mathrm{PO}_{4}} \cdot \mathrm{K}_{\mathrm{a}}}{\left[\mathrm{H}^{+}\right]+\mathrm{K}_{\mathrm{a}}}
\end{gathered}
$$

The values $\mathrm{k}_{\mathrm{pH}}, \mathrm{k}_{\mathrm{B},} \mathrm{k}_{\mathrm{H}_{3} \mathrm{PO}_{4}}$, and $\mathrm{k}_{\mathrm{H}_{2} \mathrm{PO}_{4}}$ - were calculated from equations 4 and 5 (Table 2).

Under the conditions of this study, the rate constants $\left(\mathrm{k}_{\mathrm{obs}}\right)$ did not depend on the total concentrations of the phosphate $(\mathrm{pH}=5.84-7.25)$, acetate $(\mathrm{pH}=3.65-5.48)$ and borate $(7.49-10.07)$ buffers, which indicated that the components of the buffers did not catalyze the degradation of CFT. The parallelism test was used to verify that the differences between $\mathrm{k}_{\text {obs. }}$ determined at different buffer concentrations were not statistically significant. Since in the reaction solutions of $\mathrm{CFT}$ in $\mathrm{HCl}$, phosphate $(\mathrm{pH}$ $=5.84-7.25)$, acetate and borate buffers as well as in $\mathrm{NaOH}$ general acid-base catalysis was not observed, in those solutions $\mathrm{k}_{\mathrm{obs} .}=\mathrm{k}_{\mathrm{pH}}$.

pH-rate profiles. The $\mathrm{k}_{\mathrm{pH}}$ determined in hydrochloric acid, sodium hydroxide, phosphate, borate and acetate buffers and under the conditions of general acid-base catalysis ( $\mathrm{pH} 1.54-2.95)$ were used to calculate the relationship $\log \mathrm{k}_{\mathrm{pH}}=\mathrm{f}(\mathrm{pH})$ (Fig. 5).

Table 2. The values of $\mathrm{k}_{\mathrm{pH}}$ and $\mathrm{k}_{\mathrm{B}}$ for the degradation of ceftiofur sodium in phosphate buffer at $323 \mathrm{~K}$.

\begin{tabular}{|c|c|c|c|}
\hline $\mathrm{pH}$ & $\mathrm{k}_{\mathrm{pH}} \pm \mathrm{Dk}_{\mathrm{pH}}$ & $\mathrm{k}_{\mathrm{B}} \pm \mathrm{Dk}_{\mathrm{B}}$ & Catalytic effect of buffer components \\
\hline 1.54 & $(2.12 \pm 3.04) 10^{-6}$ & $(4.61 \pm 3.04) 10^{-6}$ & \\
\hline 2.53 & $(1.97 \pm 4.83) 10^{-6}$ & $(10.151 \pm 22.37) 10^{-6}$ & $\mathrm{k}_{\mathrm{H}_{3} \mathrm{PO}_{4}}=1.08 \mathrm{~L} \mathrm{~mol}^{-1} \mathrm{~s}^{-1}$ \\
\hline 2.95 & $(1.90 \pm 1.62) 10^{-6}$ & $(4.99 \pm 6.13) 10^{-6}$ & $\mathrm{k}_{\mathrm{H}_{2} \mathrm{PO}_{4}}=1.66 \mathrm{~L} \mathrm{~mol}^{-1} \mathrm{~s}^{-1}$ \\
\hline
\end{tabular}


The semilogarithmic relationship $\mathrm{k}_{\mathrm{pH}}-\mathrm{pH}$ indicated that in water solutions at $\mathrm{pH} 0.44-12.43$ the following reactions occurred:

- degradation of protonated molecules and zwitterions of CFT catalyzed by hydrogen ions $\left(\mathrm{k}_{\mathrm{H}}^{+}\right.$and $\left.\mathrm{k}_{\mathrm{H}}{ }^{+}\right)$

- spontaneous hydrolysis of monoanions of CFT under the influence of water $\left(\mathrm{k}_{\mathrm{H}_{2} \mathrm{O}}\right)$

- degradation of monoanions of CFT catalyzed by hydroxide ions $\left(\mathrm{k}_{\mathrm{OH}}{ }^{-}\right)$.

The total reaction rate was equal to the sum of partial reaction rates:

$$
\begin{gathered}
\mathrm{k}_{\mathrm{pH}}=\mathrm{k}_{\mathrm{H}}^{+} \cdot \mathrm{a}_{\mathrm{H}}^{+} \cdot \mathrm{f}_{1}+\mathrm{k}^{\prime}{ }_{\mathrm{H}}^{+} \cdot \mathrm{a}_{\mathrm{H}}^{+} \cdot \mathrm{f}_{2}+\mathrm{k}_{\mathrm{H}_{2} \mathrm{O}} \cdot \mathrm{f}_{3} \\
+\mathrm{k}_{\mathrm{OH}}{ }^{-} \cdot \mathrm{a}_{\mathrm{OH}} \cdot \mathrm{f}_{3}
\end{gathered}
$$

where: $\mathrm{a}_{\mathrm{H}}{ }^{+}$and $\mathrm{a}_{\mathrm{OH}^{-}}-$activities of the hydrogen and hydroxide ions, respectively, $\mathrm{f}_{1}-\mathrm{f}_{3}-$ the fractions of the molecules of CFT (protonated molecules, zwitterions and monoanions), calculated from the values of $\mathrm{pK}_{\mathrm{a}}$ of CFT that were 1.70 and 2.63 at $323 \mathrm{~K}$.

The catalytic rate constant $\mathrm{k}_{\mathrm{OH}}{ }^{-}$was calculated from the plot $\mathrm{k}_{\mathrm{pH}}=\mathrm{f}\left(\mathrm{a}_{\mathrm{OH}^{-}}\right)$for the $\mathrm{pH}$ range above 5 , in which $\mathrm{f}_{3} \rightarrow 1$. The plot $\mathrm{k}_{\mathrm{pH}}=\mathrm{f}\left(\mathrm{a}_{\mathrm{OH}^{-}}\right)$was linear with a positive slope that was equal to $\mathrm{k}_{\mathrm{OH}^{-}}{ }^{-}$(Fig. 6). The catalytic rate constants of the hydrolysis of protonated molecules and zwitterions of CFT under the influence of hydrogen ions were calculated for the $\mathrm{pH}$ range $0.44-1.54$, in which $\mathrm{f}_{1}+\mathrm{f}_{2} \rightarrow 1$ from the following equation:

$$
\mathrm{k}_{\mathrm{pH}}=\mathrm{k}_{\mathrm{H}}{ }^{+} \cdot \mathrm{a}_{\mathrm{H}}{ }^{+} \cdot \mathrm{f}_{1}+\mathrm{k}_{\mathrm{H}}{ }^{+} \cdot \mathrm{a}_{\mathrm{H}}{ }^{+} \cdot \mathrm{f}_{2}
$$

The plot $\mathrm{k}_{\mathrm{pH}} / \mathrm{a}_{\mathrm{H}}{ }^{+}=\mathrm{f}\left(\mathrm{f}_{2}\right)$ was linear (Fig. 7). The catalytic rate constants $\mathrm{k}_{\mathrm{H}}{ }^{+}\left(1.48 \times 10^{-5} \mathrm{~L} \mathrm{~mol}^{-1} \mathrm{~s}^{-1}\right)$ and $\mathrm{k}_{\mathrm{H}}{ }^{+}\left(1.77 \times 10^{-4} \mathrm{~L} \mathrm{~mol}^{-1} \mathrm{~s}^{-1}\right)$ were equal to the values of $\mathrm{k}_{\mathrm{pH}} / \mathrm{a}_{\mathrm{H}}+$ for $\mathrm{f}_{2}=1$ and for $\mathrm{f}_{2}=0$, respectively.

The catalytic rate constant of the spontaneous hydrolysis of CFT monoanions was calculated from equation (9) as the mean values of $\mathrm{k}_{\mathrm{pH}}$ at $\mathrm{pH} 3.65-$ $6.78\left(\mathrm{k}_{\mathrm{H}_{2} \mathrm{O}}=2.02 \times 10^{-6} \mathrm{~s}^{-1}\right)$ :

$\mathrm{k}_{\mathrm{pH}}{ }^{2}=\mathrm{k}_{\mathrm{pH}}-\left(\mathrm{k}_{\mathrm{H}}{ }^{+} \cdot \mathrm{a}_{\mathrm{H}}{ }^{+} \cdot \mathrm{f}_{2}+\mathrm{k}_{\mathrm{OH}} \cdot \mathrm{a}_{\mathrm{OH}} \cdot \mathrm{f}_{3}\right.$

The calculated theoretical profile of $\log \mathrm{k}=$ $\mathrm{f}(\mathrm{pH})$ and that obtained from the experimental results were nearly identical, indicating that the choice of the equation describing the total rate of CFT degradation was correct (Fig. 5). The pH-rate profile demonstrated that CFT was the most stable at pH 2 to 6.5, where the spontaneous hydrolysis of monoanions of CFT occurred.

\section{CONCLUSION}

The kinetic mechanism of degradation of ceftiofur sodium in the solid phase does not depend on storage conditions and can be described as a firstorder reaction relative to the substrate concentration at increased relative air humidity and at $\mathrm{RH}=0 \%$.
In aqueous solutions, in the $\mathrm{pH}$ range $0.44-12.43$, the degradation of ceftiofur sodium is a pseudo-firstorder reaction. The hydrolysis of the protonated molecules and zwitterions of CFT catalyzed by hydrogen ions, the spontaneous hydrolysis of monoanions of CFT under the influence of water and the degradation of monoanions of CFT catalyzed by hydroxide ions are the partial reactions of degradation. The catalytic effect is observed for the components of the phosphate buffer $(\mathrm{pH} 1.54-$ 2.95). Summarizing, ceftiofur sodium is the most stable in the $\mathrm{pH}$ range $2-6$.

The susceptibility of ceftiofur sodium to degradation under the influence of stress factors $(\mathrm{pH}$, temperature, buffer components and their concentrations, relative air humidity) should be considered when planning storage conditions and during pharmaceutical form preparation. It was demonstrated that ceftiofur sodium needs to be stored in tightly closed containers, protected from moisture and elevated temperature. In the process of preparing ceftiofur sodium for injection, the use of phosphate buffers should be avoided.

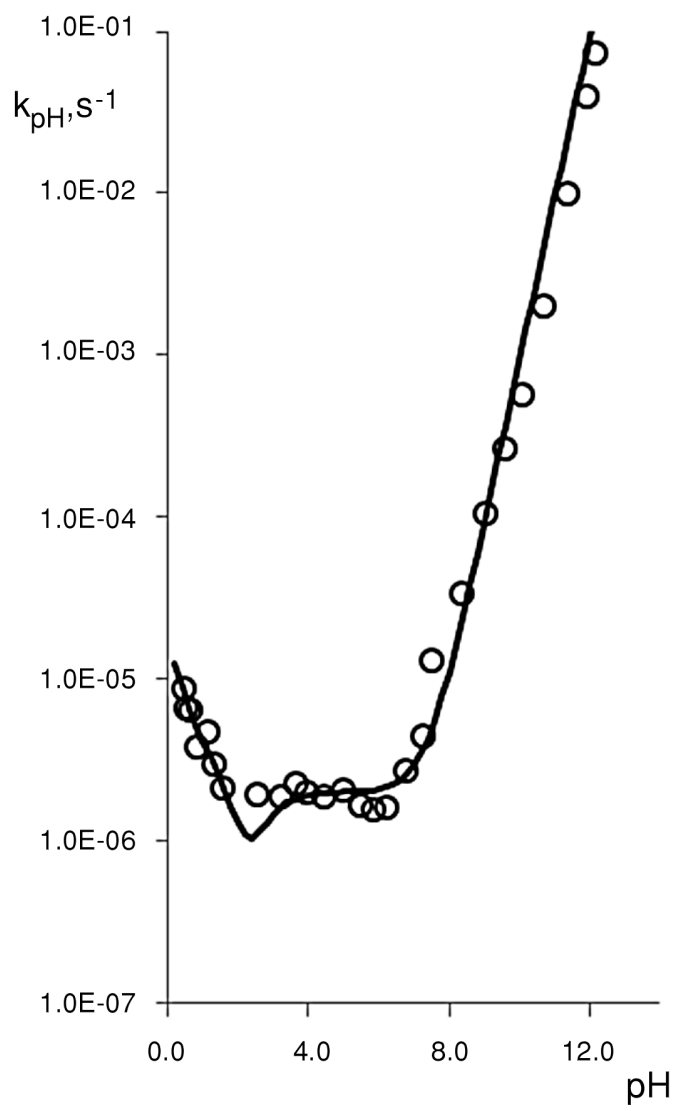

Figure 5. pH-rate profile for the degradation of ceftiofur sodium at $323 \mathrm{~K}$. The points are determined experimentally. The line was calculate from equation (7) 


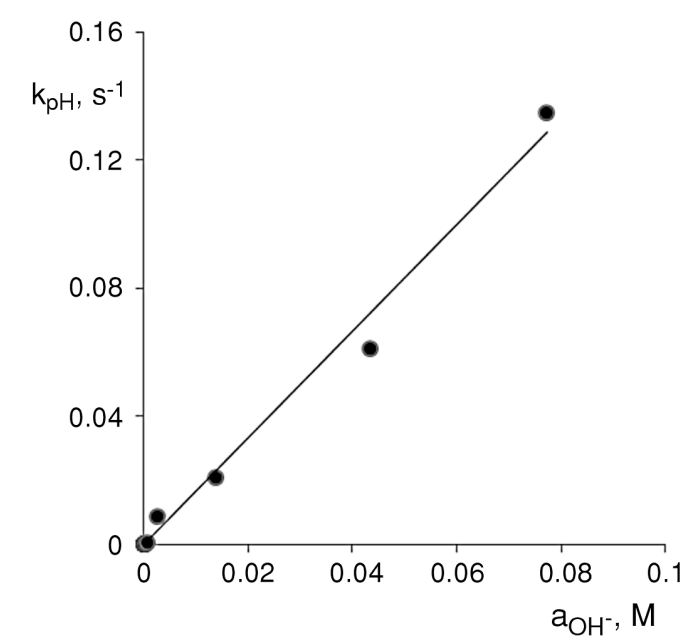

Figure 6. The plot $\mathrm{k}_{\mathrm{pH}}=\mathrm{f}\left(\mathrm{a}_{\mathrm{OH}^{-}}\right)$for the determination of ceftiofur sodium at $323 \mathrm{~K}$

\section{Conflict of interest}

The authors confirm that this article content has no conflict of interest.

\section{REFERENCES}

1. Mölbak K.: J. Vet. Med. B. 51, 364 (2004).

2. Scientific Advisory Group on Antimicrobials of the Committee for Medicinal Products for Veterinary Use: J. Vet. Pharmacol. Therap. 32, 515 (2009).

3. Ungemach F.R.: Acta Vet. Scand. 93, 89 (2000).

4. Pikkemaat M.G.: Anal. Bioanal. Chem. 395, 893 (2009).

5. Masztis P.S.: Can. Vet. J. 25, 329 (1984).

6. McEwen S.A., Black W.D., Meek A.H.: Can. Vet. J. 33, 527 (1992).

7. Althaus R.L., Molina M.P., Rodriguez M., Fernandez N.: J. Food. Prot. 64, 1844 (2001).

8. Hozová B., Minarovičová L.: Czech J. Food Sci. 19, 207 (2001).

9. Li X., Zheng W., Machesky M.L., Yates S.R., Katterhenry M.: J. Agric. Food Chem. 59, 10176 (2011).

10. Feng S., Chiesa O.A., Kijak P., Chattopadhaya Ch., Lancaster V., Smith E.A., Girard L., Sklenka S., Li H.: J. Agric. Food Chem. 62, 5011 (2014).

11. Lemke T.L., Williams D.A., Roche V.F., Zito S.W.: Foye's Principles of Medicinal Chemistry, $7^{\text {th }}$ ed., Lippincott Williams \& Wilkins, Philadelphia 2013.

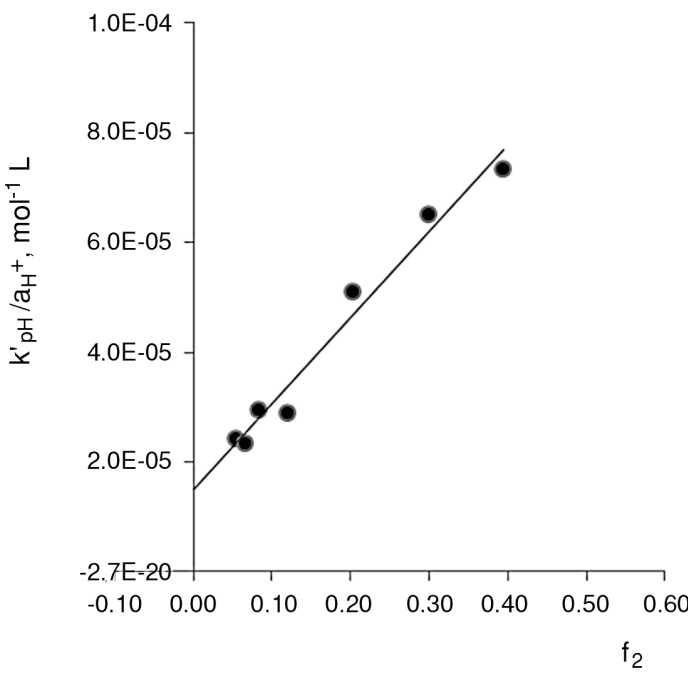

Figure 7. The plot $\mathrm{k}_{\mathrm{pH}}{ }^{\prime} / \mathrm{a}_{\mathrm{H}}+=\mathrm{f}\left(\mathrm{f}_{2}\right)$ for the determination of ceftiofur sodium at $323 \mathrm{~K}$

12. The Merck Index, Merck \& CO.INK, New Jersay 2011.

13. Burton P.J., Thornsberry C., Yee Y.Y., Watts J.L., Yancey Jr.R.J.: J. Vet. Diagn. Invest. 8, 464 (1996).

14. Salmon S.A., Watts J.L., Case C.A., Hoffman L.J., Wegner H.C., Yancey R.J.: J. Clin. Microbiol. 33, 2435 (1995).

15. Erskine R.J., Wilson R.C., Tyler J.W., McClure K.A., Nelson R.S., Spears H.J.: Am. J. Vet. Res. 56, 481 (1995).

16. Stanek C., Kofler J.: Tierarztl. Prax. Ausgabe G Grosstiere Nutztiere 26, 314 (1998).

17. Wisselink H.J., Veldman K.T., Van den Eede C., Salmon S.A., Mevius D.J.: Vet. Microbiol. 113, 73 (2006).

18. Jaglan P.S., Kubicek M.F., Arnold T.S., Cos B.L., Robin R. et al.: J. Agric. Food Chem. 37, 1112 (1989).

19. Jaglan P.S., Cox B.L., Arnold T.S., Kubicek M.F., Stuart D.J. Gilbertson T.J.: J. Assoc. Off. Anal. Chem. 73, 26 (1990).

20. Beconi-Baker M.G., Roof R.D., Millerioux L., Kausche F.M., Vidmar T.H. et al.: J. Chromatogr. B Biomed. Appl. 673, 231 (1995).

21. Food and Drug Administration: Fed. Regist. 53, 5369 (1988).

22. Food and Drug Administration: Fed. Regist. 56, 12 (1991).

23. Food and Drug Administration: Fed. Regist. 57, 41862 (1992).

24. Hornish R.E., Kotarski S.F.: Curr. Top. Med. Chem. 2, 717 (2002). 
25. Gilbertson T.J., Roof R.D., Nappier J.L., Zaya M.J., Robins R.H. et al.: J. Agric. Food Chem. 43, 229 (1995).

26. Beconi-Barker M.G., Smith E.B., Arnold T.S., Hornish R.E., Vidmar T.J., Gatchell C.L.: J. Argic. Food Chem. 45, 2606 (1997).

27. Halstead S.L., Walker R.D., Baker J.C., Holland R.E., Stein G.E., Hauptman J.G.: Can. Res. J. Vet. 56, 269 (1992).

28. Souza M.J., Nogueira D.R., Silva L.M., Arend M.Z., Souza Filho P.S., Bergold A.M.: Chromatographia 65, 401 (2007).

29. Koshy K.T., Cazers A.R.: J. Pharm. Sci. 86, 389 (1997).

30. Sunkara G., Navarre C.B., Kompella U.B.: J. Pharm. Pharmacet. 51, 249 (1999).
31. Souza M.J., Souza Filho P.S., Adams A.I.H., Bergold A.M.: The Open Antimicrob. Agent. J. 2, 1 (2010).

32. Lim Y.H., Park D.H., Young Y.Y., Kim K.H., Cho H.S.: Mass Spectrum. Lett. 2, 16 (2011).

33. Dołhań A., Jelińska A., Bębenek M.: Sci. World J. art. ID 583461, 1 (2014).

34. Salmon S.A., Watts J.L., Yancey Jr R.J.: J. Vet. Diagn. Invest. 8, 332 (1996).

35. De Baere S., Pille F., Croubels S., Ceelen L., De Backer P.: Anal. Chim. Acta. 512, 75 (2004).

36. Berendsen B.J.A., Essers M.L., Mulder P.P.J., van Bruchem G.D., Lommen A. et al.: J. Chromatogr. A 1216, 8177 (2009).

37. Pawełczyk E., Hermann T.: in The Fundamentals of stability drugs (in Polish), p. 68, PZWL, Warsaw 1982.

Received: 27. 11. 2017 